\title{
Cigarette Smoke Amplifies Inflammatory Response and Atherosclerosis Progression Through Activation of the H1R-TLR2/4-COX2 Axis
}

\author{
Rajat S. Barua ${ }^{1}$, Mukut Sharma ${ }^{2}$ and Kottarappat N. Dileepan ${ }^{3 *}$
}

${ }^{1}$ Division of Cardiovascular Medicine, Kansas City Veterans Affairs Medical Center, Kansas City, MO, USA, ${ }^{2}$ Research Service, Kansas City Veterans Affairs Medical Center, Kansas City, MO, USA, ${ }^{3}$ Department of Medicine, Division of Allergy, Clinical Immunology and Rheumatology, University of Kansas Medical Center, Kansas City, KS, USA

OPEN ACCESS

Edited by:

Masaaki Murakami, Hokkaido University, Japan

Reviewed by: Hiroki Kimura,

Hokkaido University, Japan Keigo Nishida,

Suzuka University of Medical

Science, Japan

*Correspondence:

Kottarappat N. Dileepan kdileepan@kumc.edu

Specialty section: This article was submitted to Inflammation,

a section of the journal

Frontiers in Immunology

Received: 06 August 2015 Accepted: 26 October 2015 Published: 09 November 2015

Citation:

Barua RS, Sharma M and Dileepan KN (2015) Cigarette Smoke Amplifies Inflammatory Response and

Atherosclerosis Progression Through Activation of the H1R-TLR2/4-COX2 Axis.

Front. Immunol. 6:572. doi: 10.3389/fimmu.2015.00572
Emerging evidence suggests that infection and persistent inflammation are key players in the pathogenesis of atherosclerotic cardiovascular disease (CVD). Although it is well established that cigarette smoke (CS) promotes atherosclerotic CVD, very little is known about the potential impact of the collective effects of CS and intermittent or chronic subclinical infection on atherosclerosis. Our previous studies demonstrated that mast cell-derived histamine and lipopolysaccharide (LPS) synergistically enhance endothelial cell inflammatory response. We further noted that the synergy between histamine and LPS was due to reciprocal upregulation of histamine receptor and Toll-like receptor 4 (TLR4) expression and functions. These results suggest that the combined and persistent effects of mast cell mediators and bacterial agents on the vasculature are risk factors of CVD. Our recent data demonstrated that CS extract enhances histamine- and LPS-induced expression of cyclooxygenase-2 (COX-2) in endothelial cells, suggesting that CS and mast cell mediators may collectively amplify inflammatory response in the vessel wall. We hypothesize that CS enhances histamine-mediated upregulation of TLR2/TLR4 signaling in the endothelium and promotes progression of atherosclerosis. This article presents our perspective on the modulatory effects of CS and nicotine on the "histamine-TLR-COX-2 axis."

Keywords: cigarette smoking, infection, atherosclerosis, mast cells, lipopolysaccharide, histamine, cyclooxygenase-2, toll-like receptors 2 and 4

\section{INTRODUCTION}

Atherosclerosis (AS) is the underlying cause of several cardiovascular disease (CVD)-associated complications, including myocardial infarction (MI), heart failure, and stroke. Early stages of atherogenesis involve endothelial cell activation, persistent inflammatory response, and altered vascular homeostasis. The fact that the ever-changing milieu of endothelial cells alters cytokine profile, prostanoid homeostasis, and oxidative stress and attracts proinflammatory cells strengthens the notion that AS is an inflammatory disease. 
It is recognized that both innate and adaptive immune systems contribute to the inflammatory processes in AS. In this respect, the role of T-lymphocytes, B-cells, macrophages, dendritic cells, natural killer cells, and neutrophils has been extensively studied. Furthermore, the presence of increased number of mast cells (1-4) and their influence in modulating toll-like receptors (TLRs) appear to be key contributors to the atherosclerotic process (5, 6 ). The mechanisms by which mast cell-mediated upregulation of innate immune system promote progression of AS remain obscure.

Toll-like receptors are expressed in a variety of cell types including endothelial cells (5). The presence of TLR2 and TLR4 in endothelial cells and their link to the COX-2 pathway add to the interaction between the innate immune system and AS. Our laboratory was the first to report the synergy between histamine and TLR2/TLR4 signaling that leads to overexpression of COX-2 and IL-6 in human coronary artery endothelial cells (HCAECs) (5-7). We demonstrated that the synergy between histamine and bacterial agents is due to reciprocal upregulation of the expression of histamine $\mathrm{H} 1$ receptor (H1R), TLR2, and TLR4. These findings strongly suggest that histamine can amplify endothelial inflammatory responses initiated by both Gram-positive and Gram-negative bacterial products.

Cigarette smoke (CS) is a major lifestyle-related risk factor for CVD. However, the impact of CS on intermittent or chronic subclinical infection-induced vascular inflammation and atherogenic pathobiology is unclear. It is well recognized that cigarette smoking increases the risk of microbial infection (8), and CS induces histamine release from mast cells (9). Thus, it is reasonable to postulate that cross-communication between CS, histamine, and bacterial products may lead to amplified inflammatory response. Here, we present a novel paradigm that CS promotes atherogenesis by modulating mast cell-mediated innate immune upregulation and by enhancing persistent vascular inflammation.

\section{ENDOTHELIAL CELLS AND EARLY EVENTS IN ATHEROSCLEROSIS}

Endothelial cells constitute the initial site of vascular changes that evolve into life-threatening occlusive lesions. The endothelium covers the tunica intima of the vessel wall and is directly exposed to the circulating milieu and pathogens. Further into the wall, the tunica media contains most of the resident smooth muscle cells and the adventitia on the outside contains mast cells, nerve endings, and microvessels. Endothelial cell activation by bloodborne proinflammatory agents shifts the vascular tone and local vascular homeostasis which, in turn, increase the risk of accelerated development of atherosclerotic lesions (10).

Activation of endothelial cells also increases the expression of adhesion molecules (VCAM-1, ICAM-1, and E-selectin) (11) that recruit monocytes, T-cells, B-cells, dendritic cells, mast cell precursors, and neutrophils into the vascular wall where lowdensity lipoprotein (LDL)-laden monocytes mature into foam cells. Altered vessel wall environment promotes smooth muscle cell proliferation and causes their migration from the media to the intima where they synthesize matrix proteins including collagen, elastin, and proteoglycans. Immune cells in the developing plaque between endothelial cells and the adventitia release proinflammatory cytokines, matrix metalloproteinases (MMPs), and reactive oxidants, which ultimately lead to plaque rupture and occlusive event (12).

Cardiovascular disease risk factors including cigarette smoking, hypercholesterolemia, and oxidative stress cause early endothelial dysfunction leading to atherosclerotic changes. Endothelial dysfunction is indicated by decreased production of vasodilatory and homeostatic molecules such as nitric oxide (NO) and prostacyclin (prostaglandin $\mathrm{I}_{2}, \mathrm{PGI}_{2}$ ) or increased production of vasoconstrictive molecules such as endothelin-1 (ET-1) and thromboxane $\mathrm{A}_{2}\left(\mathrm{TXA}_{2}\right)$. Early endothelial dysfunction promotes the transformation of quiescent endothelial cells toward an active phenotype that involves host defense response (13).

\section{ROLE OF CYCLOOXYGENASE-2 AND PROSTANOIDS IN VASCULAR INFLAMMATION AND ATHEROSCLEROSIS}

The COX isozymes in concert with specific isomerases modulate cellular homeostasis and vascular tone through the production of several prostanoids. COX-1 is constitutively expressed in most cells, whereas COX-2 expression is induced at sites of inflammation. COX-2 expression is upregulated in activated macrophages and endothelial cells, which makes it a target for the regulation of atherogenesis $(7,14)$. Although COX-2 expression is transient in acute inflammation, it can be prolonged or persistent in immune disorders (15).

Biological effects of COX products depend on their relative concentrations and receptor densities as well as the cell types and microenvironment. Among the prostanoids, $\mathrm{PGI}_{2}$ and $\mathrm{TXA}_{2}$ have received considerable attention because of their opposing effects in the vasculature (16). Specific threshold levels of their concentrations in systemic circulation and vascular tissues are prerequisite for vascular homeostasis (17). $\mathrm{PGI}_{2}$ functions as a potent vasodilator and inhibitor of leukocyte adhesion and platelet aggregation. Early depletion of $\mathrm{PGI}_{2}$ from endothelium promotes AS by enhancing lipid deposition in smooth muscle cells (18). In contrast, $\mathrm{TXA}_{2}$ is a potent inducer of vasoconstriction, platelet activation, and platelet adhesion. Therefore, a shift in the $\mathrm{PGI}_{2} / \mathrm{TXA}_{2}$ equilibrium may dictate the vascular tone.

Our previous work focused on the interaction between histamine and lipopolysaccharide (LPS) with regard to COX-2 expression in endothelial cells $(6,7)$. The preferential effect of histamine on the induction of COX-2 expression with resultant production of $\mathrm{PGE}_{2}$ and $\mathrm{PGI}_{2}$ and its lack of influence on $\mathrm{COX}-1$ expression or $\mathrm{TXA}_{2}$ production support the concept of a distinct coupling of COX-2 with $\mathrm{PGE}_{2}$ and $\mathrm{PGI}_{2}$ synthases and that of COX-1 with $\mathrm{TXA}_{2}$ synthase. It is intriguing that, despite the coexistence of both COX-1 and COX-2 in HCAEC, histamine is able to segregate its influence on $\mathrm{COX}-2 / \mathrm{PGE}_{2} / \mathrm{PGI}_{2}$ pathway and not on $\mathrm{COX}-1 /$ $\mathrm{TXA}_{2}$ pathway. The ability of histamine to synergize LPS-induced COX-2 expression and prostanoid production underscores the potential role of this mast cell mediator to amplify infectionassociated inflammatory responses. Since a physiological balance 
in the production of $\mathrm{PGI}_{2}$ and $\mathrm{TXA}_{2}$ by endothelial cells is critical for maintaining vascular integrity and controlling thrombosis, the histamine-induced shift of prostanoid equilibrium in favor of $\mathrm{PGI}_{2}$ production is noteworthy and supports its well-recognized vasodilatory and vasoprotective functions.

\section{ROLE OF MAST CELLS IN VASCULAR INFLAMMATION AND ATHEROSCLEROSIS}

Mast cells alter the tissue microenvironment and modulate vascular inflammation, progression of AS, cardiac ischemia, and CVD (19). Mast cell progenitors reach the tissue through a chemokine-mediated mechanism and differentiate into mucosal or connective tissue phenotypes. Mucosal mast cells are characterized by the presence of only tryptase and chondroitin sulfate (proteoglycan), whereas connective tissue mast cells contain tryptase as well as chymase and heparin (proteoglycan) (20). Mast cells release vasoactive and angiogenic compounds and proinflammatory mediators, such as arachidonic acid metabolites (prostaglandin $\mathrm{D}_{2}$, leukotrienes), histamine, cytokines (e.g., IL-6 and IFN $\gamma$ ) and chemokines (e.g., eotaxin, MCP-1, and RANTES), platelet-activating factor (PAF), heparin, and proteolytic enzymes (21). These effector molecules are packaged in electron-dense secretory granules (mast cell granules, MCG). Endothelial cells can endocytose MCG in vitro (22) and in vivo (23). MCG can also promote human microvascular endothelial cell proliferation (24), LDL uptake by macrophages, and foam cell formation $(21,25)$.

Risk factors such as hypercholesterolemia, hyperglycemia, proinflammatory cytokines, oxidized LDL, reactive oxygen species, complement 5 a, substance $\mathrm{P}$, endothelin-1, and thrombin can activate mast cells (25). Mast cells express proangiogenic cytokine $\beta F G F$ and participate in neovascularization and release histamine that increases vascular permeability and proinflammatory effects on endothelial cells (26-28). Clinical significance of mast cells is evident by their accumulation in the human arterial intima and adventitia where they contribute to atherosclerotic plaque development as well as its destabilization through their secretory products $(21,22,29)$. Increased number of mast cells is noted in coronary arteries during spasm and in the rupture-prone shoulders of coronary atheromas (2). Although these findings implicate mast cells in vascular homeostasis, the mechanism by which they promote atherogenesis and CVD is not well understood.

The direct role of mast cells in AS is evident from studies by us and others, showing attenuation of AS progression in $A p o E^{-1-}$ /

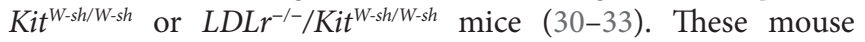
models are generated by crossing AS-prone $A \mathrm{poE}^{-/-}$or $\mathrm{LDLr}^{-/-}$ mice with mast cell-deficient $\mathrm{Kit}^{W-s h / W-s h}$ mice. Using $A p o E^{-/-} /$ $K i t^{W-s h / W-s h}$ mice, we demonstrated that mast cell deficiency attenuates AS progression in $A p o E^{-/-}$mice. Interestingly, the reduction in atheroma development in $A p o E^{-/-} / K i t^{W-s h / W-s h}$ mice was associated with marked decreases in hepatic steatosis, reduced serum levels of cholesterol, LDL, and HDL, and decreased number of T-lymphocytes and macrophages in atheromas. Furthermore, $A p o E^{-/-} / K i t^{W-s h / W-s h}$ mice presented significantly lower serum IL-6 and IL-10, with no changes in the levels of IL-2, IL-4, IL-17, IFN $\gamma$, and TNF $\alpha$. Mast cell deficiency did not reduce serum levels of
IFN $\gamma$ in the $A p o E^{-/-}$mice, suggesting that mast cell-derived IFN $\gamma$ may not play a role in this mouse model of AS as opposed to the $L D L r^{-/-}$mouse model $(31,34)$. Mast cell deficiency did not alter systemic production of $\mathrm{TXA}_{2}$ in $A p o E^{-/-}$mice but led to significant reduction in the production of $\mathrm{PGI}_{2}$. Significantly lower expression of COX-2 mRNA in the aortic tissues of $A p o E^{-/-} \mathrm{Kit}^{\mathrm{W}-\mathrm{sh} / \mathrm{W}-\mathrm{sh}}$ mice compared with that of $A p o E^{-/-}$mice suggests that mast cells regulate COX-2 expression. In this regard, the ability of histamine to induce COX-2 expression and $\mathrm{PGI}_{2}$ production in human endothelial cells and the markedly reduced expression of COX-2 mRNA in the aorta of histidine decarboxylase-null mouse (7) emphasize the importance of histamine in prostanoid homeostasis. Taken together, the marked reduction of hypercholesterolemia and vascular inflammation due to mast cell deficiency may attenuate AS progression in $A p o E^{-/-} / K_{i t} t^{W-s h / W-s h}$ mice.

\section{ROLE OF HISTAMINE AND H1 RECEPTOR IN ENDOTHELIAL CELL INFLAMMATORY RESPONSE}

Histamine is a major secretory product of the mast cell that regulates vasodilation and bronchoconstriction $(33,35)$ and acts in combination with proteases to destabilize the plaque (35). Histamine induces smooth muscle cell migration and proliferation (36) and regulates intimal thickening (37). Histamine also regulates functions of monocytes and macrophages and eosinophils $(38,39)$, T-cells (40), neutrophils, and endothelial cells (41, 42). Histamine acts through a family of four distinct G-proteincoupled receptors (GPCR), namely, H1R, H2R, H3R, and H4R (43-45). Endothelial cells and smooth muscle cells highly express H1R, which facilitates histamine-mediated inflammatory and hypersensitivity responses $(5-7,33,35,36)$.

The role of histamine in AS and myocardial damage began to emerge only recently (46-48). Coronary arteries of patients with ischemic heart disease contain more mast cells and histamine than normal vessels (46), and patients with variant angina have elevated levels of histamine in their coronary circulation (49). Increased H1R mRNA expression has been reported in smooth muscle cells of intima/media in the atheroma (50). We found that histamine acting through H1R stimulates the expression of IL- 6 and COX-2, with increased production of $\mathrm{PGI}_{2}$ by human endothelial cells. Interestingly, these effects are synergistically enhanced by LPS which suggests that mast cell products and bacterial agents act in concert to enhance vascular inflammation.

\section{INFECTION, INFLAMMATION, AND ATHEROSCLEROSIS}

Current literature strongly suggests a key role for infectionrelated immune activation in AS. Chlamydia pneumoniae, Porphyromonas gingivalis, Aggregatibacter actinomycetemcomitans, Helicobacter pylori, and cytomegalovirus have been shown to be present in plaques and to promote AS in animals (51-56). LPS, a cell wall glycolipid of Gram-negative bacteria, induces the production of proinflammatory cytokines and the expression of adhesion molecules on endothelial cells. Gram-positive bacterial 
cell wall components, peptidoglycan (PGN) and lipoteichoic acid (LTA), also induce endothelial cell activation $(5,6)$. LPS is detectable in apparently healthy individuals with subclinical or chronic infections such as periodontitis, sinusitis, bronchitis, or diverticulitis. Persistent LPS levels as low as $50 \mathrm{pg} / \mathrm{mL}$ may be a strong risk factor for AS, particularly among smokers. Our studies demonstrated that bacterial toxins and histamine synergistically enhance endothelial inflammatory response through overexpression of TLR2 and TLR4 (5-7).

Activation of endothelial cells by pathogen-associated molecular patterns (PAMPs) and/or molecules from damaged host tissues induce the expression of inflammatory cytokines and cell adhesion molecules (57-60). TLRs are innate immune receptors that recognize PAMPs (61). TLR4 is the signaling receptor for LPS or heat shock protein-60 (human and chlamydial) $(62,63)$. TLR2 recognizes Gram-positive bacterial, mycobacterial, and fungal cell wall components $(64,65)$.

Increasing evidence suggests that TLR2 and TLR4 modulate vascular inflammation and atherosclerotic disease $(66,67)$. Endothelial layers of atherosclerotic lesions express higher levels of TLR2 and TLR4 mRNA, and patients with loss-of-function TLR4 polymorphism have reduced risk of CVD (68). Mutations in TLR4 have been linked with a lower incidence of AS and other CVDs (69). Furthermore, TLR4 gene deletion reduces vascular inflammation and atherogenesis in $A p o E^{-/-}$mouse (70). Anecdotally, it is believed that viral or bacterial infection increases the chances for "acute coronary syndrome." Despite putative significance of TLR2 and TLR4 in AS (67-70), an association between their expression in the plaque and severity of atherosclerotic disease is not established. Our preliminary clinical study showed an association between overexpression of TLR2, TLR4, and COX-2 in the carotid artery plaque and the severity of widespread AS including the presence of peripheral artery disease (71). These observations underscore the clinical significance of an overactive TLR2/TLR4/COX-2 axis in CVD.

\section{THE SYNERGY BETWEEN MAST CELL HISTAMINE AND BACTERIAL TOXINS}

The TLR-mediated endothelial response to bacterial pathogens may be modulated by mast cell mediators. Our studies show that histamine acting through $\mathrm{H} 1 \mathrm{R}$ stimulates the expression of TLR2, TLR4, IL-6, COX-2, $\mathrm{PGI}_{2} \mathrm{~S}$, and $\mathrm{PGE}_{2} \mathrm{~S}$ genes, leading to enhanced production of IL-6, $\mathrm{PGE}_{2}$, and $\mathrm{PGI}_{2}$ by HCAECs (5-7). We recently showed that LPS upregulates H1R gene and protein expression in HCAECs. We also noted that LPS-exposed HCAECs expressed threefold higher H1R than quiescent cells as assessed by H1R ligand binding. Furthermore, these cells were hyperresponsive to histamine as indicated by increased production of $\mathrm{PGI}_{2}, \mathrm{PGE}_{2}$, and IL-6. The LPS-induced hyperresponsiveness to histamine challenge was found to be mediated via $\mathrm{H} 1 \mathrm{R}$ since it was abrogated by H1R antagonists $(5-7,72,73)$. Thus, convergence of reciprocally upregulated H1R and TLR2/TLR4 functions was evident by the enhanced translocation of NF- $\mathrm{KB}$ and inflammatory response in endothelial cells treated with histamine in the presence of TLR ligands (74).

\section{CIGARETTE SMOKE, INNATE IMMUNE SYSTEM, AND ATHEROSCLEROSIS}

Cigarette smoke is a major cause of cardiovascular morbidity and mortality $(75,76)$. CS predisposes the individual to aortic and peripheral AS leading to clinical atherosclerotic syndromes, including stable angina, acute coronary syndromes, sudden death, and stroke (75). CS impacts all phases of AS from endothelial dysfunction to acute clinical events, the latter being largely thrombotic (77-84).

TLR recognition is not restricted to exogenous microbial patterns. Putative endogenous ligands include fibronectin extra domain A fragment, heat shock proteins, and hyaluronan fragments. Endogenous ligands may be released during tissue damage and drive inflammation in the absence of infection. Therefore, a risk factor like CS can potentially promote inflammation via these ligands. Indeed, gaseous and particulate

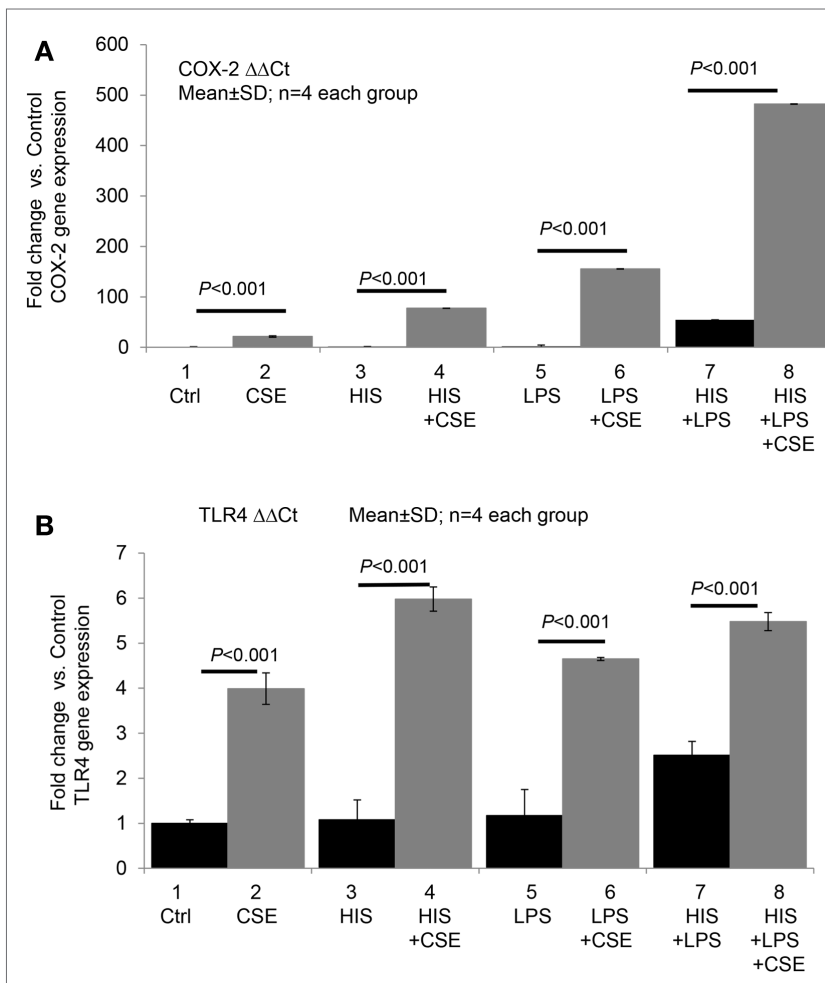

FIGURE 1 | Cigarette smoke extract directly and synergistically with histamine or LPS enhances the expression of COX-2 and TLR4 in human endothelial cells. Human umbilical vein endothelial cells (HUVECs) were grown to confluence and incubated with (1) medium (control), (2) cigarette smoke extract (CSE) (final concentration equivalent to $100 \mathrm{nM}$ nicotine), (3) histamine (HIS, $10 \mu \mathrm{M})$, (4) HIS + CSE, (5) LPS, $100 \mathrm{ng} / \mathrm{mL}$, (6) LPS + CSE, (7) HIS + LPS, and (8) HIS + LPS + CSE for $24 \mathrm{~h}$. After the incubation, total RNA was extracted and used for RT-qPCR analyses of gene expressions of COX-2 (A) and TLR4 (B). Data presented are mean \pm SD of quadruplicate experiments. CS increased COX2 gene expression significantly compared to control, HIS, LPS, or HIS + LPS groups $(P<0.001)$. HIS + LPS (6) increased COX2 expression compared to control, HIS, or LPS groups $(P<0.001)$. CS increased TLR4 gene expression significantly compared to control, HIS, LPS, or HIS + LPS groups $(P<0.001)$. HIS + LPS (6) increased TLR4 expression compared to control, HIS, or LPS groups $(P<0.001)$. 
constituents of CS increase TLR2, 4, and 6 expression by gingival epithelial cells (85). It is worth mentioning that CS may deliver bioactive LPS to smokers which may contribute to bronchitis in smokers. However, these investigators did not detect differences in the circulating levels of LPS between non-smokers and smokers (86).

Cigarette smoke upregulates both TLR4 expression and the release of IL- 8 and LTB4 in alveolar macrophages (87). CS also induces TLR4 and MMP4 expression in human small airway epithelial (SAE) cells and lung tissue (88). Furthermore, CS has been shown to activate mast cells to release preformed mediators such as histamine and to inhibit prostaglandin production (34).

It is noteworthy that CS not only induces COX-2 expression and its enzyme activity but also increases $\mathrm{PGE}_{2}$ and TXA $\mathrm{T}_{2}$ release $(89,90)$. CS extract (CSE) and sera from smokers increase COX-2 expression in endothelial cells (91), and this change is associated with augmented angiogenesis in the atherosclerotic plaque. CS may exert proinflammatory effects in a $\mathrm{PGE}_{2}$-dependent manner while $\mathrm{TXA}_{2}$ may mediate its proatherogenic effect via platelet activation, vasoconstriction, and angiogenesis (91).

\section{THE "H1R-TLR-COX2 AXIS" - AN INTEGRATED APPROACH TO STUDY THE IMMUNOMODULATORY EFFECTS OF CS AND INFECTION ON ATHEROGENESIS}

We recently conducted a pilot study to test whether CSE directly or synergistically modulates the effect of histamine or LPS on
COX-2 and TLR4 expression in endothelial cells. Briefly, human umbilical vein endothelial cells (HUVECs) were incubated with medium (control), histamine, or LPS alone and in combination with CSE for $24 \mathrm{~h}$ (see Figure 1). As shown in Figure 1A, CSE significantly increased the basal as well as histamine- and LPS-induced COX-2 gene expression with varying magnitudes of synergy. Similarly, CSE significantly enhanced the expression of TLR4 mRNA in quiescent and in histamine- and LPS-treated cells (Figure 1B). These results indicate that CS can upregulate COX-2 and TLR4 pathways.

We also examined the effect of histamine on the expression of nicotinic acetylcholine receptor $\alpha 1$ (NAChR $\alpha 1)$ mRNA in HUVECs. Histamine upregulated NAChR $\alpha 1$ gene expression, which was enhanced by LPS (data not shown). These findings suggest that histamine increases endothelial cell sensitivity to nicotine and CS through overexpression of NAChR $\alpha 1$. The involvement of other nicotinic acetylcholine receptors as well as receptors that recognize unidentified factors in CSE remains to be determined. Based on these preliminary results, our published work $(5-7,72-75,77-83)$ and a recent clinical study correlating TLR2, TLR4, and COX-2 overexpression in carotid artery plaques with the severity of disease (71), we postulate that constituents of CS, acting in concert with bacterial toxins and mast cell products, may amplify inflammatory response by engaging the H1R-TLR2/ TLR4-COX2 axis (Figure 2).

\section{CONCLUSION}

Mast cells and TLRs are constituents of the innate immune system, and they synergistically enhance proatherogenic

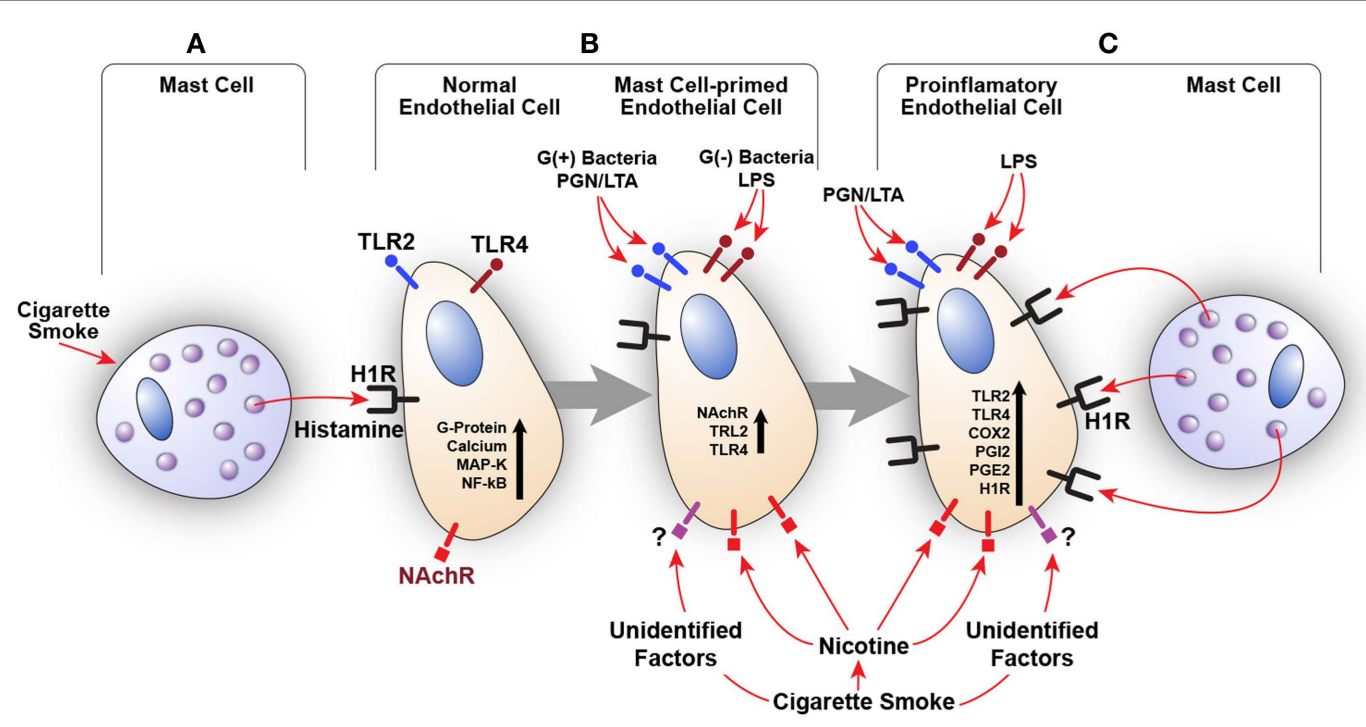

FIGURE 2 | Amplification of endothelial inflammatory response by cigarette smoke (CS) and bacterial products via innate immune upregulation. (A) Histamine secreted by the mast cell stimulates H1R on endothelial cells. CS may also increase histamine release. (B) H1R-mediated endothelial cell activation leads to increased expression of TLR2/TLR4 and nicotinic acetylcholine receptors (NAChR). This cross talk programs endothelial cells to become hyperresponsive to the TLR2/TLR4 ligands (PGN, LTA, and LPS) and CS leading to enhanced inflammatory response. (C) Increased TLR2/TLR4 signaling also increases H1R expression. Collective stimulation of newly expressed TLR2/TLR4 and H1R leads to robust proinflammatory changes in the endothelium and persistent vascular inflammation. 
inflammatory response in endothelial cells. Our published work shows that histamine acting via H1R, and in conjunction with TLR2 or TLR4 ligands, synergistically amplifies the expression of COX-2 and IL- 6 in endothelial cells with resultant overproduction of $\mathrm{PGI}_{2}, \mathrm{PGE}_{2}$, and IL-6. Preliminary data also show that CS extract enhances histamine- and LPS-induced endothelial expression of COX-2 and TLR4 in a synergistic manner, and histamine induces NAChR $\alpha 1$ expression. We propose that whole CS as well as its constituents such as nicotine modulate innate immune system and amplify infectionmediated proatherogenic inflammatory responses to promote the onset and progression of AS.

\section{REFERENCES}

1. Davies MJ. The composition of coronary-artery plaques. N Engl J Med (1997) 336(18):1312-4. doi:10.1056/NEJM199705013361809

2. Ross R. Atherosclerosis - an inflammatory disease. N Engl J Med (1999) 340(2):115-26. doi:10.1056/NEJM199901143400207

3. Glass CK, Witztum JL. Atherosclerosis. The road ahead. Cell (2001) 104(4):503-16. doi:10.1016/S0092-8674(01)00238-0

4. Hansson GK, Libby P, Schonbeck U, Yan ZQ. Innate and adaptive immunity in the pathogenesis of atherosclerosis. Circ Res (2002) 91(4):281-91. doi:10.1161/01.RES.0000029784.15893.10

5. Talreja J, Kabir MH, B Filla M, Stechschulte DJ, Dileepan KN. Histamine induces toll-like receptor 2 and 4 expression in endothelial cells and enhances sensitivity to Gram-positive and Gram-negative bacterial cell wall components. Immunology (2004) 113(2):224-33. doi:10.1111/j.1365-2567.2004.01946.x

6. Raveendran VV, Tan X, Sweeney ME, Levant B, Slusser J, Stechschulte DJ, et al. Lipopolysaccharide induces $\mathrm{H} 1$ receptor expression and enhances histamine responsiveness in human coronary artery endothelial cells. Immunology (2011) 132(4):578-88. doi:10.1111/j.1365-2567.2010.03403.x

7. Tan X, Essengue S, Talreja J, Reese J, Stechschulte DJ, Dileepan KN. Histamine directly and synergistically with lipopolysaccharide stimulates cyclooxygenase-2 expression and prostaglandin $\mathrm{I}(2)$ and $\mathrm{E}(2)$ production in human coronary artery endothelial cells. J Immunol (2007) 179(11):7899-906. doi:10.4049/jimmunol.179.11.7899

8. Brian D, Carter BD, Abnet CC, Feskanich D, Freedman ND, Hartge P, et al. Smoking and mortality - beyond established causes. N Engl J Med (2015) 372(7):631-40. doi:10.1056/NEJMsa1407211

9. Thomas PS, Schreck RE, Lazarus SC. Tobacco smoke releases performed mediators from canine mast cells and modulates prostaglandin production. Am J Physiol (1992) 263(1 Pt 1):L67-72.

10. Stoll LL, Denning GM, Weintraub NL. Potential role of endotoxin as a proinflammatory mediator of atherosclerosis. Arterioscler Thromb Vasc Biol (2004) 24(12):2227-36. doi:10.1161/01.ATV.0000147534.69062.dc

11. Ling S, Nheu L, Komesaroff PA. Cell adhesion molecules as pharmaceutical target in atherosclerosis. Mini Rev Med Chem (2012) 12(2):175-83. doi:10.2174/138955712798995057

12. Libby P, Ridker PM, Hansson GK. Progress and challenges in translating the biology of atherosclerosis. Nature (2011) 473:317-25. doi:10.1038/ nature 10146

13. Liao JK. Linking endothelial dysfunction with endothelial cell activation. $J$ Clin Invest (2013) 123(2):540-1. doi:10.1172/JCI66843

14. Smith DD, Tan X, Tawfik O, Milne G, Stechschulte DJ, Dileepan KN. Increased aortic atherosclerotic plaque development in female apolipoprotein E-null mice is associated with elevated thromboxane A2 and decreased prostacyclin production. J Physiol Pharmacol (2010) 61(3):309-16.

15. Vane J, Corin RE. Prostacyclin: a vascular mediator. Eur J Vasc Endovasc Surg (2003) 26(6):571-8. doi:10.1016/S1078-5884(03)00385-X

16. Dubois RN, Abramson SB, Crofford L, Gupta RA, Simon LS, Van De Putte LB, et al. Cyclooxygenase in biology and disease. FASEB J (1998) 12(12):1063-73.

17. Kobayashi T, Tahara Y, Matsumoto M, Iguchi M, Sano H, Murayama T, et al. Roles of thromboxane A(2) and prostacyclin in the development of atherosclerosis in apoE-deficient mice. J Clin Invest (2004) 114(6):784-94. doi:10.1172/ JCI200421446

\section{ACKNOWLEDGMENTS}

The work summarized here was supported by NIH grants R01HL070101 and 3R01-HL070101-04S1, Joseph and Elizabeth Carey Arthritis Fund and Audrey E. Smith Medical Research Fund from KU Endowment Association, and the Department of Internal Medicine Research Office at the University of Kansas Medical Center. The authors also thank the Kansas City VA Medical Center and the Midwest Biomedical Research Foundation, Kansas City, MO, USA, for their support. Authors wish to sincerely thank Dr. Jianping Zhou, Dr. Alok De, Ms. Maohui Chen and Mr. Siddharth Sharma for the data incorporated in Figure 1.

18. Gryglewski RJ, Dembinska-Kiec A, Korbut R. A possible role of thromboxane A2 (TXA2) and prostacyclin (PGI2) in circulation. Acta Biol Med Ger (1978) 37(5-6):715-23.

19. Constantinides P. Mast cells and susceptibility to experimental atherosclerosis. Science (1953) 117(3045):505-6. doi:10.1126/science.117.3045.505

20. Kaartinen M, Penttilä A, Kovanen PT. Mast cells of two types differing in neutral protease composition in the human aortic intima. Demonstration of tryptase and tryptase/chymase-containing mast cells in normal intimas, fatty streaks, and the shoulder region of atheromas. Arterioscler Thromb (1994) 14(6):966-72. doi:10.1161/01.ATV.14.6.966

21. Bot I, Shi GP, Kovanen PT. Mast cells as effectors in atherosclerosis. Arterioscler Thromb Vasc Biol (2015) 35(2):265-71. doi:10.1161/ATVBAHA.114.303570

22. Krishnaswamy G, Ajitawi O, Chi DS. The human mast cell: an overview. Methods Mol Biol (2006) 315:13-34.

23. Spinas E, Kritas SK, Saggini A, Mobili A, Caraffa A, Antinolfi P, et al. Role of mast cells in atherosclerosis: a classical inflammatory disease. Int $J$ Immunopathol Pharmacol (2014) 27(4):517-21.

24. Marks RM, Roche WR, Czerniecki M, Penny R, Nelson DS. Mast cell granules cause proliferation of human microvascular endothelial cells. Lab Invest (1986) 55(3):289-94.

25. $\mathrm{Xu}$ J, Shi GP. Vascular wall extracellular matrix proteins and vascular diseases. Biochim Biophys Acta (2014) 1842(11):2106-19. doi:10.1016/j. bbadis.2014.07.008

26. Kamat BR, Galli SJ, Barger AC, Lainey L, Silverman KJL. Neovascularization and coronary atherosclerotic plaque: cinematographic localization and quantitative histologic analysis. Hum Pathol (1987) 18(10):1036-42. doi:10.1016/ S0046-8177(87)80220-4

27. Kaartinen M, Pentillä A, Kovanen PT. Mast cells accompany microvessels in human coronary atheromas: implications for intimal neovascularization and hemorrhage. Atherosclerosis (1996) 123(1-2):123-31. doi:10.1016/0021-9150(95)05794-3

28. Lappalainen H, Laine P, Pentikäinen MO, Sajantila A, Kovanen PT. Mast cells in neovascularized human coronary plaques store and secrete basic fibroblast growth factor, a potent angiogenic mediator. Arterioscler Thromb Vasc Biol (2004) 24(10):1880-5. doi:10.1161/01.ATV.0000140820.51174.8d

29. Theoharides TC, Sismanopoulos N, Delivanis DA, Zhang B, Hatziagelaki EE, Kalogeromitros D. Mast cells squeeze the heart and stretch the gird: their role in atherosclerosis and obesity. Trends Pharmacol Sci (2011) 32(9):534-42. doi:10.1016/j.tips.2011.05.005

30. Jeziorska M, McCollum C, Woolley DE. Mast cell distribution, activation, and phenotype in atherosclerotic lesions of human carotid arteries. J Pathol (1997) 182(1):115-22. doi:10.1002/ (SICI) 1096-9896(199705)182:1<115::AID-PATH806>3.0.CO;2-9

31. Heikkila HM, Trosien J, Metso J, Jauhiainen M, Pentikainen MO, Kovanen PT, et al. Mast cells promote atherosclerosis by inducing both an atherogenic lipid profile and vascular inflammation. J Cell Biochem (2010) 109(3):615-23. doi:10.1002/jcb.22443

32. Smith DD, Tan X, Raveendran VV, Tawfik O, Stechschulte DJ, Dileepan KN. Mast cell deficiency attenuates progression of atherosclerosis and hepatic steatosis in apolipoprotein E-null mice. Am J Physiol Heart Circ Physiol (2012) 302(12):H2612-21. doi:10.1152/ajpheart.00879.2011

33. Hill SJ. Multiple histamine receptors: properties and functional characteristics. Biochem Soc Trans (1992) 20(1):122-5. doi:10.1042/bst0200122 
34. Sun J, Sukhova GK, Wolters PJ, Yang M, Kitamoto S, Libby P, et al. Mast cells promote atherosclerosis by releasing proinflammatory cytokines. Nat Med (2007) 13(6):719-24. doi:10.1038/nm1601

35. Ozben B, Erdogan O. The role of inflammation and allergy in acute coronary syndromes. Inflamm Allergy Drug Targets (2008) 7(3):136-44. doi:10.2174/187152808785748128

36. Bottaro D, Shepro D, Peterson S, Hechtman HB. Serotonin, histamine, and norepinephrine mediation of endothelial and vascular smooth muscle cell movement. Am J Physiol (1985) 248(3 Pt 1):C252-7.

37. Miyazawa N, Watanabe S, Matsuda A, Kondo K, Hashimoto H, Umemura $\mathrm{K}$, et al. Role of histamine $\mathrm{H} 1$ and $\mathrm{H} 2$ receptor antagonists in the prevention of intimal thickening. Eur J Pharmacol (1998) 362(1):53-9. doi:10.1016/ S0014-2999(98)00716-X

38. Elenkov IJ, Webster E, Papanicolaou DA, Fleisher TA, Chrousos GP, Wilder RL. Histamine potently suppresses human IL-12 and stimulates IL-10 production via H2 receptors. J Immunol (1998) 161(5):2586-93.

39. Dileepan KN, Lorsbach RB, Stechschulte DJ. Mast cell granules inhibit macrophage-mediated lysis of mastocytoma cells (P815) and nitric oxide production. J Leukoc Biol (1993) 53(4):446-53.

40. Beer DJ, Matloff SM, Rocklin RE. The influence of histamine on immune and inflammatory responses. Adv Immunol (1984) 35:209-68. doi:10.1016/ S0065-2776(08)60577-5

41. Jeannin P, Delneste Y, Gosset P, Molet S, Lassalle P, Hamid Q, et al. Histamine induces interleukin-8 secretion by endothelial cells. Blood (1994) 84(7):2229-33.

42. Li Y, Chi L, Stechschulte DJ, Dileepan KN. Histamine-induced production of interleukin- 6 and interleukin- 8 by human coronary artery endothelial cells is enhanced by endotoxin and tumor necrosis factor-alpha. Microvasc Res (2001) 61(3):253-62. doi:10.1006/mvre.2001.2304

43. Bakker RA, Timmerman H, Leurs R. Histamine receptors: specific ligands, receptor biochemistry, and signal transduction. Clin Allergy Immunol (2002) 17:27-64.

44. Hill SJ, Ganellin CR, Timmerman H, Schwartz JC, Shankley NP, Young JM, et al. International Union of Pharmacology. XIII. Classification of histamine receptors. Pharmacol Rev (1997) 49(3):253-78.

45. Leurs R, Watanabe T, Timmerman H. Histamine receptors are finally 'coming out'. Trends Pharmacol Sci (2001) 22:337-9. doi:10.1016/ S0165-6147(00)01691-6

46. Kalsner S, Richards R. Coronary arteries of cardiac patients are hyperreactive and contain stores of amines: a mechanism for coronary spasm. Science (1984) 223(4643):1435-7. doi:10.1126/science.6701530

47. Cabanié $\mathrm{M}$, Godfraind $\mathrm{T}$. The role of histamine in the cardiovascular system. Drugs Exp Clin Res (1988) 14(2-3):141-7.

48. Schneider E, Rolli-Derkinderen M, Arock M, Dy M. Trends in histamine research: new functions during immune responses and hematopoiesis. Trends Immunol (2002) 23(5):255-63. doi:10.1016/S1471-4906(02)02215-9

49. Sakata Y, Komamura K, Hirayama A, Nanto S, Kitakaze M, Hori M, et al. Elevation of the plasma histamine concentration in the coronary circulation in patients with variant angina. Am J Cardiol (1996) 77(12):1121-6. doi:10.1016/ S0002-9149(96)00147-6

50. Takagishi T, Sasaguri Y, Nakano R, Arima N, Tanimoto A, Fukui H, et al. Expression of the histamine $\mathrm{H} 1$ receptor gene in relation to atherosclerosis. Am J Pathol (1995) 46(4):981-8.

51. Armingohar Z, Jorgensen JJ, Kristoffersen AK, Abesha-Belay E, Olsen I. Bacteria and bacterial DNA in atherosclerotic plaque and aneurysmal wall biopsies from patients with and without periodontitis. J Oral Microbiol (2014) 6. doi:10.3402/jom.v6.23408

52. Kozarov EV, Dorn BR, Shelburne CE, Dunn WA Jr, Progulske-Fox A. Human atherosclerotic plaque contains viable invasive Actinobacillus actinomycetemcomitans and Porphyromonas gingivalis. Arterioscler Thromb Vasc Biol (2005) 25:e17-8. doi:10.1161/01.ATV.0000155018.67835.1a

53. Velsko IM, Chukkapalli SS, Rivera MF, Lee JY, Chen H, Zheng D, et al. Active invasion of oral and aortic tissues by Porphyromonas gingivalis in mice causally links periodontitis and atherosclerosis. PLoS One (2014) 9:e97811. doi:10.1371/journal.pone.0097811

54. Thomas GS, Wann LS, Allam AH, Thompson RC, Michalik DE, Sutherland ML, et al. Why did ancient people have atherosclerosis?: from autopsies to computed tomography to potential causes. Glob Heart (2014) 9(2):229-37. doi:10.1016/j.gheart.2014.04.002
55. Hussain M, Stover CM, Dupont A. P. gingivalis in periodontal disease and atherosclerosis - scenes of action for antimicrobial peptides and complement. Front Immunol (2015) 6:45. doi:10.3389/fimmu.2015.00045

56. Hettne KM, Weeber M, Laine ML, ten Cate H, Boyer S, Kors JA, et al. Automatic mining of the literature to generate new hypotheses for the possible link between periodontitis and atherosclerosis: lipopolysaccharide as a case study. J Clin Periodontol (2007) 34(12):1016-24. doi:10.1111/j.1600-051X.2007.01152.x

57. Pober JS, Cotran RS. Cytokines and endothelial cell biology. Physiol Rev (1990) 70(2):427-51.

58. PoberJS,CotranRS.Theroleofendothelialcellsininflammation.Transplantation (1990) 50(4):537-44. doi:10.1097/00007890-199010000-00001

59. Mantovani A, Bussolino F, Dejana E. Cytokine regulation of endothelial cell function. FASEB J (1992) 6(8):2591-9.

60. Morrison DC, Lei MG, Chen TY, FlebbeLM, Halling J, FieldS. Identification and characterization of mammalian cell membrane receptors for LPS-endotoxin. Adv Exp Med Biol (1992) 319:23-9. doi:10.1007/978-1-4615-3434-1_3

61. Cybulsky MI, Chan MK, Movat HZ. Acute inflammation and microthrombosis induced by endotoxin, interleukin-1, and tumor necrosis factor and their implication in gram-negative infection. Lab Invest (1988) 58(4):365-78.

62. Medzhitov R, Janeway CA Jr. Decoding the patterns of self and nonself by the innate immune system. Science (2002) 296(5566):298-300. doi:10.1126/ science. 1068883

63. Hoshino K, Takeuchi O, Kawai T, Sanjo H, Ogawa T, Takeda Y, et al. Cutting edge: toll-like receptor 4 (TLR4)-deficient mice are hyporesponsive to lipopolysaccharide: evidence for TLR4 as the Lps gene product. J Immunol (1999) 162(7):3749-52.

64. Poltorak A, He X, Smirnova I, Liu MY, Van Huffel C, Du X, et al. Defective LPS signaling in $\mathrm{C} 3 \mathrm{H} / \mathrm{HeJ}$ and $\mathrm{C} 57 \mathrm{BL} / 10 \mathrm{ScCr}$ mice: mutations in Tlr4 gene. Science (1998) 282(5396):2085-8. doi:10.1126/science.282.5396.2085

65. Takeuchi O, Hoshino K, Kawai T, Sanjo H, Takada H, Ogawa T, et al. Differential roles of TLR2 and TLR4 in recognition of gram-negative and gram-positive bacterial cell wall components. Immunity (1999) 11(4):443-51. doi:10.1016/S1074-7613(00)80119-3

66. Lehner MD, Morath S, Michelsen KS, Schumann RR, Hartung T. Induction of cross-tolerance by lipopolysaccharide and highly purified lipoteichoic acid via different toll-like receptors independent of paracrine mediators. J Immunol (2001) 166(8):5161-7. doi:10.4049/jimmunol.166.8.5161

67. Pasterkamp G, Van Keulen JK, De Kleijn DP. Role of toll-like receptor 4 in the initiation and progression of atherosclerotic disease. Eur J Clin Invest (2004) 34(5):328-34. doi:10.1111/j.1365-2362.2004.01338.x

68. Ding Y, Subramanian S, Montes VN, Goodspeed L, Wang S, Han C, et al. Toll-like receptor 4 deficiency decreases atherosclerosis but does not protect against inflammation in obese low-density lipoprotein receptor-deficient mice. Arterioscler Thromb Vasc Biol (2012) 32(7):1596-604. doi:10.1161/ ATVBAHA.112.249847

69. Kiechl S, Lorenz E, Reindl M, Wiedermann CJ, Oberhollenzer F, Bonora E, et al. Toll-like receptor 4 polymorphisms and atherogenesis. $N$ Engl J Med (2002) 347(3):185-92. doi:10.1056/NEJMoa012673

70. Michelsen KS, Wong MH, Shah PK, Zhang W, Yano J, Doherty TM, et al. Lack of toll-like receptor 4 or myeloid differentiation factor 88 reduces atherosclerosis and alters plaque phenotype in mice deficient in apolipoprotein E. Proc Natl Acad Sci U S A (2004) 101(29):10679-84. doi:10.1073/pnas.0403249101

71. Cherian G, Tan X, Cherian R, Dileepan KN. Overexpression of toll-like receptor-2 in human carotid artery plaques reflects clinical severity of atherosclerotic disease. FASEB J (2013) 27:Abstract 735.2.

72. Li Y, Stechschulte AC, Smith DD, Lindsley HB, Stechschulte DJ, Dileepan KN. Mast cell granules potentiate endotoxin-induced interleukin- 6 production by endothelial cells. J Leukoc Biol (1997) 62(2):211-6.

73. Jehle AB, Li Y, Stechschulte AC, Stechschulte DJ, Dileepan KN. Endotoxin and mast cell granule proteases synergistically activate human coronary artery endothelial cells to generate interleukin-6 and interleukin-8. J Interferon Cytokine Res (2000) 20(4):361-8. doi:10.1089/107999000312298

74. Chi L, Stehno-Bittel L, Smirnova I, Stechschulte DJ, Dileepan KN. Signal transduction pathways in mast cell granule-mediated endothelial cell activation. Mediators Inflamm (2003) 12(2):79-87. doi:10.1080/0962935031000097682

75. Ambrose JA, Barua RS. The pathophysiology of smoking and cardiovascular disease: an update. (State of the art paper). J Am Coll Cardiol (2004) 43:1731-7. doi:10.1016/j.jacc.2003.12.047 
76. Barnett PG, Hamlett-Berry K, Sung HY, Max W. Health care expenditures attributable to smoking in military veterans. Nicotine Tob Res (2015) 17(5):586-91. doi:10.1093/ntr/ntu187

77. Barua RS, Ambrose JA, Eales-Reynolds LJ, DeVoe MC, Zervas JG, Saha DC. Dysfunctional endothelial nitric oxide biosynthesis in healthy smokers with impaired endothelium-dependent vasodilatation. Circulation (2001) 104(16):1905-10. doi:10.1161/hc4101.097525

78. Barua RS, Ambrose JA, Eales-Reynolds LJ, DeVoe MC, Zervas JG, Saha DC. Heavy and light cigarette smokers have similar dysfunction of endothelial vasoregulatory activity: an in vivo and in vitro correlation. J Am Coll Cardiol (2002) 39(11):1758-63. doi:10.1016/S0735-1097(02)01859-4

79. Barua RS, Ambrose JA, Saha DC, Eales-Reynolds LJ. Smoking is associated with altered endothelial-derived fibrinolytic and anti-thrombotic factors: an in vitro demonstration. Circulation (2002) 106(8):905-8. doi:10.1161/01. CIR.0000029091.61707.6B

80. Barua RS, Ambrose JA, Srivastava S, DeVoe MC, Eales-Reynolds LJ. Reactive oxygen species are involved in smoking-induced dysfunction of nitric oxide biosynthesis and upregulation of endothelial nitric oxide synthase in human coronary artery endothelial cells. Circulation (2003) 107(18):2342-7. doi:10.1161/01.CIR.0000066691.52789.BE

81. Barua RS, Sy F, Srikanth S, Huang G, Javed U, Buhari C, et al. Effects of cigarette smoke exposure on clot dynamics and fibrin structure. An ex-vivo investigation. Arterioscler Thromb Vasc Biol (2010) 30(1):75-9. doi:10.1161/ ATVBAHA.109.195024

82. Barua RS, Sy F, Srikanth S, Huang G, Javed U, Buhari C, et al. Acute cigarette smoke exposure reduces clot lysis - association between altered fibrin architecture and the response to t-PA. Thromb Res (2010) 126(5):426-30. doi:10.1016/j.thromres.2010.07.021

83. Barua RS, Ambrose JA. Mechanisms of coronary thrombosis in cigarette smoke exposure. Arterioscler Thromb Vasc Biol (2013) 33(7):1460-7. doi:10.1161/ ATVBAHA.112.300154

84. Messner B, Bernhard D. Smoking and cardiovascular disease: mechanisms of endothelial dysfunction and early atherogenesis. Arterioscler Thromb Vasc Biol (2014) 34(3):509-15. doi:10.1161/ATVBAHA.113.300156

85. Semlali A, Witoled C, Alanazi M, Rouabhia M. Whole cigarette smoke increased the expression of TLRs, HBDs, and proinflammatory cytokines by human gingival epithelial cells through different signaling pathways. PLoS One (2012) 7(12):e52614. doi:10.1371/journal.pone.0052614
86. Hasday JD, Bascom R, Costa JJ, Fitzgerald T, Dubin W. Bacterial endotoxin is an active component of cigarette smoke. Chest (1999) 115(3):829-35. doi:10.1378/chest.115.3.829

87. Yin Y, Hou G, Li E, Wang Q, Kang J. PPAR $\gamma$ agonists regulate tobacco smoke-induced toll like receptor 4 expression in alveolar macrophages. Respir Res (2014) 11(15):28. doi:10.1186/1465-9921-15-28

88. Geraghty P, Dabo AJ, D’Armiento J. TLR4 protein contributes to cigarette smoke-induced matrix metalloproteinase-1 (MMP-1) expression in chronic obstructive pulmonary disease. J Biol Chem (2011) 286(34):30211-8. doi:10.1074/jbc.M111.238824

89. McAdam BF, Byrne D, Morrow JD, Oates JA. Contribution of cyclooxygenase-2 to elevated biosynthesis of thromboxane A2 and prostacyclin in cigarette smokers. Circulation (2005) 112(7):1024-9. doi:10.1161/ CIRCULATIONAHA.105.542696

90. Huang WC, Chai CY, Chen WC, Hou MF, Wang YS, Chiu YC, et al. Histamine regulates cyclooxygenase 2 gene activation through Orail-mediated NFKB activation in lung cancer cells. Cell Calcium (2011) 50(1):27-35. doi:10.1016/j. ceca.2011.04.004

91. Barbieri SS, Zacchi E, Amadio P, Gianellini S, Mussoni L, Weksler BB, et al. Cytokines present in smokers' serum interact with smoke components to enhance endothelial dysfunction. Cardiovasc Res (2011) 90(3):475-83. doi: $10.1093 / \mathrm{cvr} / \mathrm{cvr} 032$

Conflict of Interest Statement: The views expressed in this article are those of the authors and do not necessarily reflect the position or policy of the Department of Veterans Affairs or the United States Government. All authors have reviewed and approved the manuscript. All authors have read the journal's policy on conflicts of interest. None of the authors have any conflict of interest to declare regarding the contents of this paper.

Copyright (C) 2015 Barua, Sharma and Dileepan. This is an open-access article distributed under the terms of the Creative Commons Attribution License (CC BY). The use, distribution or reproduction in other forums is permitted, provided the original author(s) or licensor are credited and that the original publication in this journal is cited, in accordance with accepted academic practice. No use, distribution or reproduction is permitted which does not comply with these terms. 